\title{
A MILESTONE TO ENHANCE RUNWAY SAFETY: THE NEW GLOBAL REPORTING FORMAT
}

\section{UN HITO PARA MEJORAR LA SEGURIDAD EN LAS PISTA: EL NUEVO FORMATO GLOBAL DE INFORMES}

\author{
Arif TUNCAL ${ }^{1}$ *; Suat USLU ${ }^{2}$; Erdal DURSUN ${ }^{3}$. \\ 1. PhD Candidiate, Eskisehir Technical University, Institute of Graduate Programs, Turkey. arif.tuncal@dhmi.gov.tr \\ ${ }^{2}$. Assoc. Prof. Dr., Eskisehir Technical University, Faculty of Aeronautics and Astronautics, Turkey. \\ suslu@eskisehir.edu.tr \\ ${ }^{3}$. Asst. Prof. Dr., Nisantasi University, School of Civil Aviation, Turkey. erdal.dursun@nisantasi.edu.tr
}

*Correspondencia del Autor: Arif TUNCAL. e-mail: arif.tuncal@dhmi.gov.tr

\begin{abstract}
Runway excursion continues to cause serious deaths and economic losses in aviation. 179 people died in the accidents occurring between 2010 and 2019. The direct cost of accidents in 2019 is estimated at over \$4 billion. A new method known as Global Reporting Format (GRF) is introduced after studies carried out by the International Civil Aviation Organization (ICAO) to prevent aircraft accidents caused by runway excursion and to minimize risks associated with it. GRF is considered an important milestone to flight safety by ICAO. In this study, GRF is explained with all its components, and benefits and transition to the application process are discussed. As a result of the study, it is assessed that GRF is a positive contribution to flight safety in the process of take-off or landing by matching information about runway surface conditions obtained to the flight crews especially in adverse conditions.
\end{abstract}

Keywords: Runway; runway safety; runway excursion; global reporting format; runway condition code.

Cómo citar:

TUNCAL, Arif; USLU, Suat; DURSUN, Erdal. (2021). A MILESTONE TO ENHANCE RUNWAY

SAFETY: THE NEW GLOBAL REPORTING FORMAT. Revista de Investigaciones Universidad del Quindio, 33(1), 168-178. https://doi.org/10.33975/riuq.vol33n1.551

Información del artículo: 


\section{RESUMEN}

La excursión de pista sigue causando graves muertes y pérdidas económicas en la aviación. 179 personas murieron en los accidentes ocurridos entre 2010 y 2019. El costo directo de los accidentes en 2019 se estima en más de \$ 4 mil millones. Se introduce un nuevo método conocido como Global Reporting Format (GRF) después de estudios llevados a cabo por la Organización de Aviación Civil Internacional (OACI) para prevenir accidentes de aeronaves causados por excursiones de pista y minimizar los riesgos asociados con ella. La OACI considera que GRF es un hito importante para la seguridad de los vuelos. En este estudio, se explica GRF con todos sus componentes, y se discuten los beneficios y la transición al proceso de solicitud. Como resultado del estudio, se evalúa que GRF es una contribución positiva a la seguridad del vuelo en el proceso de despegue o aterrizaje al comparar la información sobre las condiciones de la superficie de la pista obtenida a las tripulaciones de vuelo, especialmente en condiciones adversas.

Palabras clave: Pista; seguridad de la pista; excursión de la pista; formato de notificación global; código de condición de la pista.

\section{INTRODUCTION AND BACKGROUND}

Figure 1 shows that the most important factor in commercial aircraft accidents between 2010 and 2019 was the loss of control while runway excursion ranked fourth in all fatal aircraft accidents with approximately $15.5 \%$ (Boeing, 2020:15). The direct cost of runway excursion accidents to the aviation industry in 2019 is estimated at more than \$ 4 billion (European Union Aviation Safety Agency (EASA), 2021a).

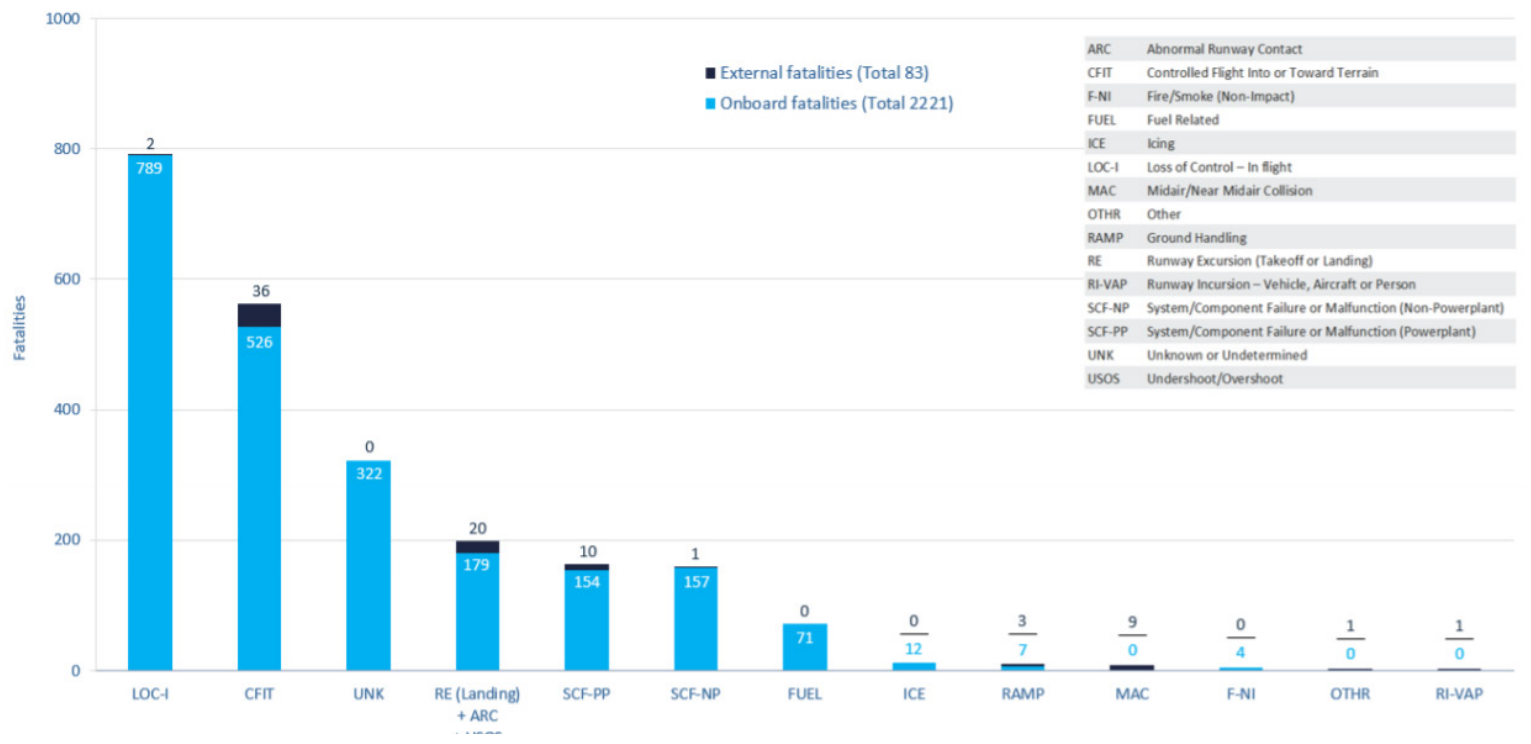

Figure 1: Accident Fatalities Between 2010 and 2019 Ref.: (Boeing, 2021:15).

Runway excursion accidents continued to occur in aviation despite the serious drop in air traffic due to crises (ICAO, 2021). Between 2008 and 2016, 402 accidents caused by runway excursion were reported to ICAO (ICAO, 2019a). Figure 2 shows the change of runway excursion accidents by years. 


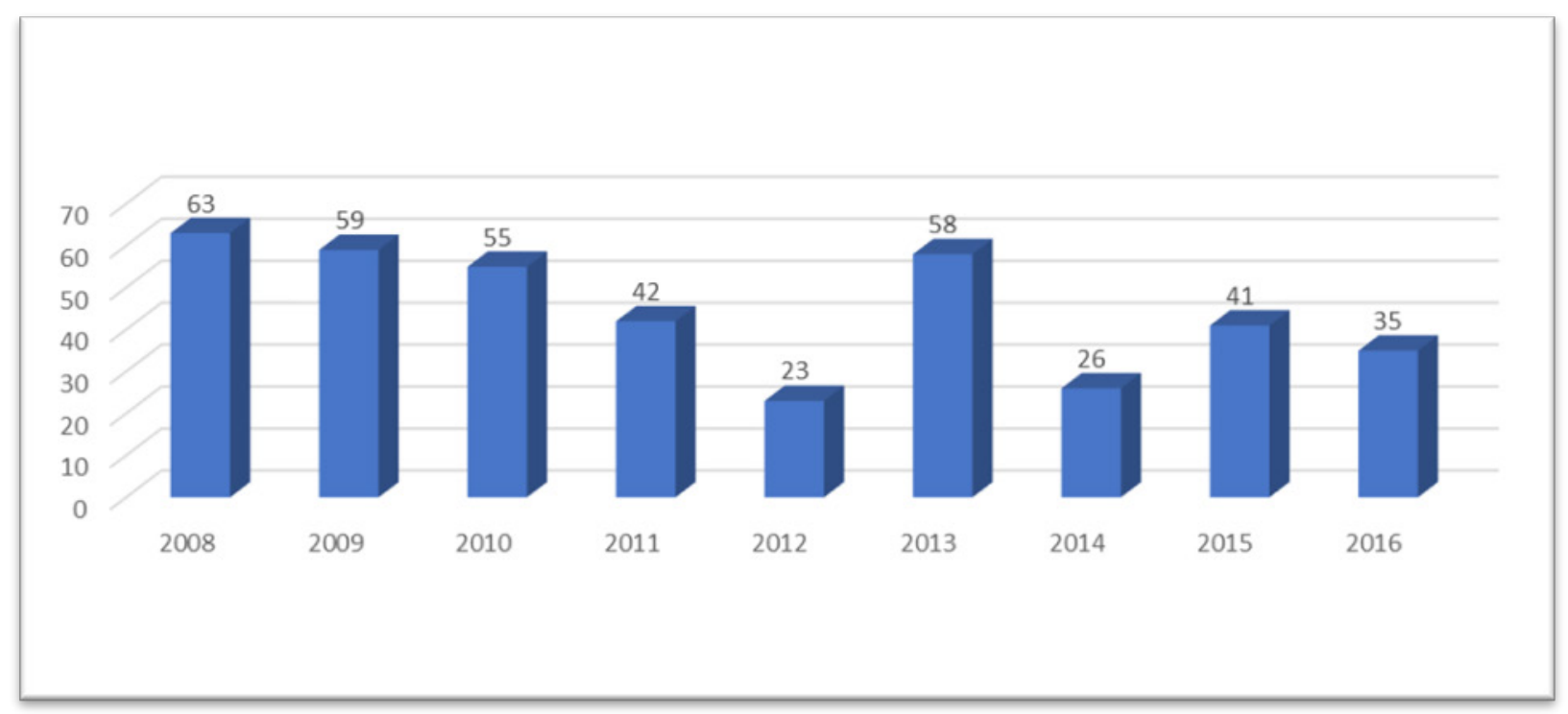

Figure 2: Runway Excursion Accidents Between 2008 and 2016

The runway excursion is classified as one of the two most important risk areas in the aviation industry (EASA,2020). The most important factor causing runway excursions is poor braking performance. It is a negative effect on the control and acceleration of the aircraft. Runway surfaces contaminated by impacting materials such as slush, snow, or ice negatively affect braking due to reducing the friction between the tires and the runway surface and/or creating a water layer between the tires and the runway. It reduces the contact area and increases the risk of aquaplaning (Gandhewar and Sonkusare, 2014:76).

Reporting, assessment and accuracy of runway surface conditions for contaminated runways affect braking performance as well as the risks associated with the runway surface and tires listed above. In a study conducted to identify factors causing runway excursion accidents, it was concluded that lack of communication is a human-induced factor, especially in the reporting and assessment of runway surface conditions (Okafar et al.,2018). In recent years, serious studies have been carried out by the aviation industry to minimize human-induced errors. Human-induced errors are one of the most important factors in aviation accidents and serious incidents.
A new method known as the Global Reporting Format (GRF) for assessing and reporting runway surface conditions was introduced by ICAO in 2016 to report runway surface conditions as standard so that the flight crew can accurately determine aircraft take-off and landing performance. It is aimed to result in a global reduction in runway excursions. GRF is information structured as a Runway Condition Report (RCR), used for aircraft performance purposes and situational awareness, containing the Runway Condition Code (RWYCC) together with a Runway Condition Assessment Matrix (RCAM). The introduction of the new GRF method reduces risks associated with runway surface conditions causing accidents.

The applicability date of the GRF has been postponed to November 4, 2021, in response to the ongoing COVID-19 pandemic and related difficulties, although it was previously specified by ICAO as November 5, 2020 (ICAO, 2016, 2020a). GRF has been implemented by the American Federal Aviation Agency (FAA) since 2016. Requirements related to GRF have been announced by the European Aviation Safety Agency (EASA) to be valid in the European Union (EU) member states as of August 12, 2021(EASA, 2021b). 


\section{MATERIALS AND METHODS}

Qualitative research is used in this research. For data collection, document analysis is used. The relevant documents were obtained from ICAO documents shown in Table 1, workshops and regional seminars held between 2019-2020, and webinars held between 2020-2021 shown in Table 2. The method was preferred because documents and visual records related to the concept subject to the study were well-organized and constantly reviewed by international aviation organizations. In-depth assessments on the subject were made by considering the data obtained through document analysis together with the literature.

Table 1: Documents Reviewed

\begin{tabular}{ll}
\hline Docs & Subject \\
\hline ICAO & Vol. I - Aerodrome Design and \\
Annex 14 & Operations \\
\hline \multirow{2}{*}{ ICAO Doc } & $\begin{array}{l}\text { Procedures For Air Navigation } \\
\text { 10066 }\end{array}$ \\
$\begin{array}{l}\text { Services (PANS) Aeronautical } \\
\text { Information Management }\end{array}$ \\
\hline ICAO & Assessment, Measurement and \\
Circular & Reporting of Runway Surface \\
355 & Conditions \\
\hline ICAO Doc & Procedures For Air Navigation \\
9981 & Services (PANS) Aerodromes \\
\hline
\end{tabular}

Table 2: Seminar and Webinars

\begin{tabular}{|c|c|}
\hline Date & Subject \\
\hline $\begin{array}{l}27- \\
28 / 06 / 2019 \\
\end{array}$ & $\begin{array}{l}\text { AOP SG3 GRF Seminar, Bangkok, } \\
\text { Thailand }\end{array}$ \\
\hline $2-3 / 07 / 2019$ & $\begin{array}{l}\text { ICAO Regional Seminar on } \\
\text { Implementation of the New GRF } \\
\text { for Runway Surface Condition, } \\
\text { Dakar. Senegal }\end{array}$ \\
\hline $\begin{array}{l}10- \\
11 / 07 / 2019\end{array}$ & $\begin{array}{l}\text { Workshop on Implementation of } \\
\text { the New GRF for Runway Surface } \\
\text { Conditions, Paris, France }\end{array}$ \\
\hline $\begin{array}{l}21-22 / 08 / \\
2019\end{array}$ & $\begin{array}{l}\text { ICAO-ACI LAC Regional Seminar } \\
\text { on GRF for Runway Conditions, } \\
\text { Lima, Peru }\end{array}$ \\
\hline $\begin{array}{l}17-18 / 10 / \\
2019\end{array}$ & $\begin{array}{l}\text { ICAO/ACI Regional Seminar } \\
\text { on the Implementation of the } \\
\text { New GRF for Runway Surface } \\
\text { Condition. Accra. Ghana }\end{array}$ \\
\hline $\begin{array}{l}28- \\
29 / 11 / 2019\end{array}$ & $\begin{array}{l}\text { Regional Seminar, Johannesburg, } \\
\text { South Africa }\end{array}$ \\
\hline
\end{tabular}

\begin{tabular}{ll}
\hline $10-$ & Regional Seminar, Frankfurt, \\
$11 / 12 / 2019$ & Germany \\
\hline $\begin{array}{l}28- \\
29 / 01 / 2020\end{array}$ & $\begin{array}{l}\text { ICAO Regional Seminar, Helsinki, } \\
\text { Finland }\end{array}$ \\
\hline $20 / 04 / 2020$ & ICAO/APAC Regional Webinar \\
\hline & $\begin{array}{l}\text { APAC- Webinar on the } \\
\text { Implementation of the New Global } \\
\text { Reporting Format for Runway } \\
\text { Surface Conditions }\end{array}$ \\
\hline $26 / 05 / 2020$ & ICAO GRF Webinar \\
\hline $18 / 05 / 2020$ & ICAO SNOWTAM Webinar \\
\hline $27 / 10 / 2020$ & ICAO CAR/SAM GRF Webinar \\
\hline $11 / 03 / 2021$ & $\begin{array}{l}\text { ICAO MID Region Webinar } \\
\text { Runway Safety Webinar }\end{array}$ \\
\hline & $\begin{array}{l}\text { EASA-Implementation Workshop } \\
\text { on the Global Reporting Format } \\
\text { for Runway Surface Conditions } \\
\text { Webinar }\end{array}$ \\
\hline
\end{tabular}

\section{THE NEW GLOBAL REPORTING FORMAT (GRF)}

A runway is a rectangular area defined in an airport for aircraft to land and take-off (ICAO, 2018a). The runway surface must be cleaned from the elements affecting the flight for any reason. However, it is not always possible for the runway surface to be at the desired level, especially due to meteorological conditions. The runway is defined to be contaminated when more than $25 \%$ of active runway surface is measured by water more than $3 \mathrm{~mm}$ deep, by slush and loose snow equivalent to more than $3 \mathrm{~mm}$ of water, snow, slush ice, or frost, and other deposits (Gandhewar and Sonkusare, 2014). Contaminated runways affect the braking performance of aircraft. For this reason, the surface conditions of the contaminated runways must be reported to the flight crew in the most accurate way to mitigate the risks.

Deficiencies of runway surface assessment and reporting methods specified in ICAO regulations and guidance material have been revealed by investigations on runway surface conditions contributed to safety incidents and accidents. In 2008, a study was initiated by ICAO to develop a guideline for the reporting of runway surface conditions in a standard manner on the assessment of the runway surface conditions and operational requirements for aircraft performance. This study This study results in the new global reporting 
format (GRF). GRF enables the transition from assessment of surface friction characteristics to an assessment of the runway surface condition in a consistent relationship to aircraft braking performance (ICAO, 2019b).

GRF concept consists of assessing the runway with a matrix through human observation and reporting a Runway Condition Report (RCR) with Runway Condition Code (RWYCC). RWYCC is complemented by a description of the contaminated material for each third of the runway, based on its type, depth and coverage. It is used to complete a standard report called Runway Condition Report (RCR). RCR is transmitted to air traffic control (ATC) services and aviation information services (AIS) for transmission of the result of the assessment and the relevant RWYCC to pilots. Pilots use RWYCC to determine braking and directional control by correlating it with performance data provided by the aircraft manufacturer. This allows pilots to accurately calculate landing and take-off performance on contaminated runways. Another important element of the GRF is the process allowing pilots to report their observations of runway conditions, approving the RWYCC or providing a warning to changing conditions (ICAO, 2021a).

With GRF, amendments were made to Annex 3 Meteorological Service for International Air Navigation; Annex 6 Operation of Aircraft, Part I International Commercial Air Transport Aeroplanes and Part II - International General Aviation Aeroplanes; Annex 8 Airworthiness of Aircraft; Annex 14 Aerodromes, Volume I Aerodrome Design and Operations; Annex 15 Aeronautical Information Services and Procedures for Air Navigation Services (PANS), Doc 9981 (PANS-Aerodromes), Doc 10066 (PANSAIM) and Doc 4444 (PANS-ATM) documents for airport operators, aircraft manufacturers, airline operators and air navigation service providers. In addition, Circular 355 (Assessment, Measurement and Reporting of Runway Surface Conditions) and document 10064 on aircraft performance have been published as supporting material (ICAO, 2021b).

\section{Runway Condition Code (RWYCC)}

A key change in the GRF is the introduction of RYWCC. RWYCC reflects braking performance as a function of runway surface conditions. RWYCC is a code describing the runway surface condition at numbers 0 to 6 . Codes are specified in triple codes starting from the landing or takeoff direction of the runway to give information about a third of the runway as shown in Figure 3. With this information, flight crews are allowed to determine the stopping distance of the aircraft under current conditions from the performance information provided by the aircraft manufacturer. Figure 4 shows the correlation between RWYCC and the pilot reports (ICAO, 2020b).

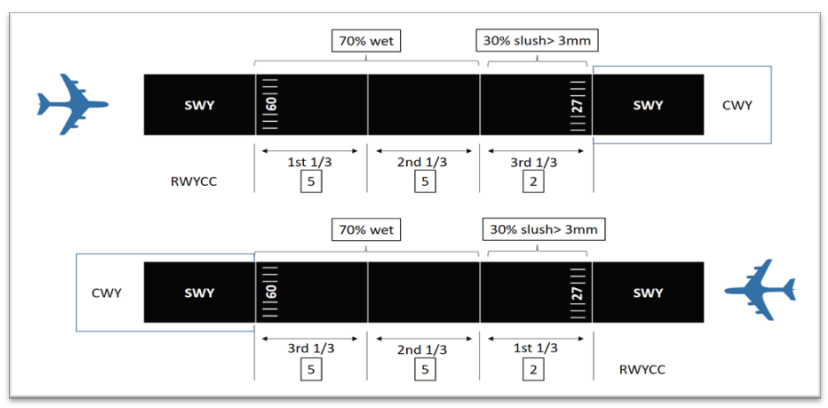

Figure 3: RWYCC Demonstration

\begin{tabular}{|c|c|c|}
\hline $\begin{array}{c}\text { Pilot report of } \\
\text { runway braking } \\
\text { action }\end{array}$ & Description & $\begin{array}{c}\text { Runway condition code } \\
(\text { RWYCC })\end{array}$ \\
\hline N/A & & 6 \\
\hline GOOD & $\begin{array}{l}\text { Braking deceleration is normal } \\
\text { for the wheel braking effort } \\
\text { applied AND directional control } \\
\text { is normal }\end{array}$ & 5 \\
\hline $\begin{array}{l}\text { GOOD TO } \\
\text { MEDIUM }\end{array}$ & $\begin{array}{l}\text { Braking deceleration OR } \\
\text { directional control is between } \\
\text { good and medium }\end{array}$ & 4 \\
\hline MEDIUM & $\begin{array}{l}\text { Braking deceleration is } \\
\text { noticeably reduced for the wheel } \\
\text { braking effort applied OR } \\
\text { directional control is noticeably } \\
\text { reduced }\end{array}$ & 3 \\
\hline MEDIUM TO POOR & $\begin{array}{l}\text { Braking deceleration OR } \\
\text { directional control is between } \\
\text { medium and poor }\end{array}$ & 2 \\
\hline POOR & $\begin{array}{l}\text { Braking deceleration is } \\
\text { significantly reduced for the } \\
\text { wheel braking effort applied OR } \\
\text { directional control is significantly } \\
\text { reduced }\end{array}$ & 1 \\
\hline LESS THAN POOR & $\begin{array}{l}\text { Braking deceleration is minimal } \\
\text { to non-existent for the wheel } \\
\text { braking effort applied OR } \\
\text { directional control is uncertain }\end{array}$ & 0 \\
\hline
\end{tabular}

Figure 4: Correlation of RWYCC and Pilot Reports of Runway Braking Action

Ref.: (ICAO, 2020b:II-2-15). 


\section{Runway Condition Assessment Matrix (RCAM)}

RCAM allows the assessment of the RWYCC based on the pilot report on the runway surface condition and braking observed using the relevant procedures. RCAM is a tool allowing airport personnel to make an assessment based on the type, depth and coverage of contaminants on the runway surface and visual observation of the air temperature (ICAO, 2019b, 2020b).

Procedures related to RCAM are global applications and are produced with the technical input of aircraft manufacturers. RCAM is valid for all conditions to be reported on a global scale and supports the classification of runway surface conditions according to effects on aircraft braking performance (ICAO, 2019b). RCAM is used by aircraft manufacturers to determine appropriate performance data for runway surface conditions and to provide data and guidance material to aircraft operators to safely continue operations on dry, wet or contaminated runway surfaces (EUROCONTROL, 2021).

A deterministic classification of the aircraft's braking performance can only be made for contaminants listed on the RCAM. Other reportable contaminants (oil, mud, ash, etc.) cause large differences in aircraft performance and provide insufficient data to allow a deterministic classification (ICAO, 2019b).

\section{Runway Condition Report (RCR)}

At a global level, runways are exposed to a wide range of climatic conditions. Therefore, there is a considerable variation in the situations to be reported. RCR describes one basic method applying to all climatic changes. ICAO member states can adjust changes according to the different climatic conditions prevailing in their regions. The concept of the RCR is premised on reporting and assessment criteria agreed by all stakeholders, RYWCC linking stated criteria, contaminant type and depth, standard terminology and phraseology, procedures to be harmonized at a global scale (ICAO, 2018a: ATT A-10).

RCR consists of a mandatory aircraft performance section and an optional situational awareness section as shown in Figure 5. Operational information on taxiways and aprons is including in the situational awareness section of the RCR (ICAO, 2020b).

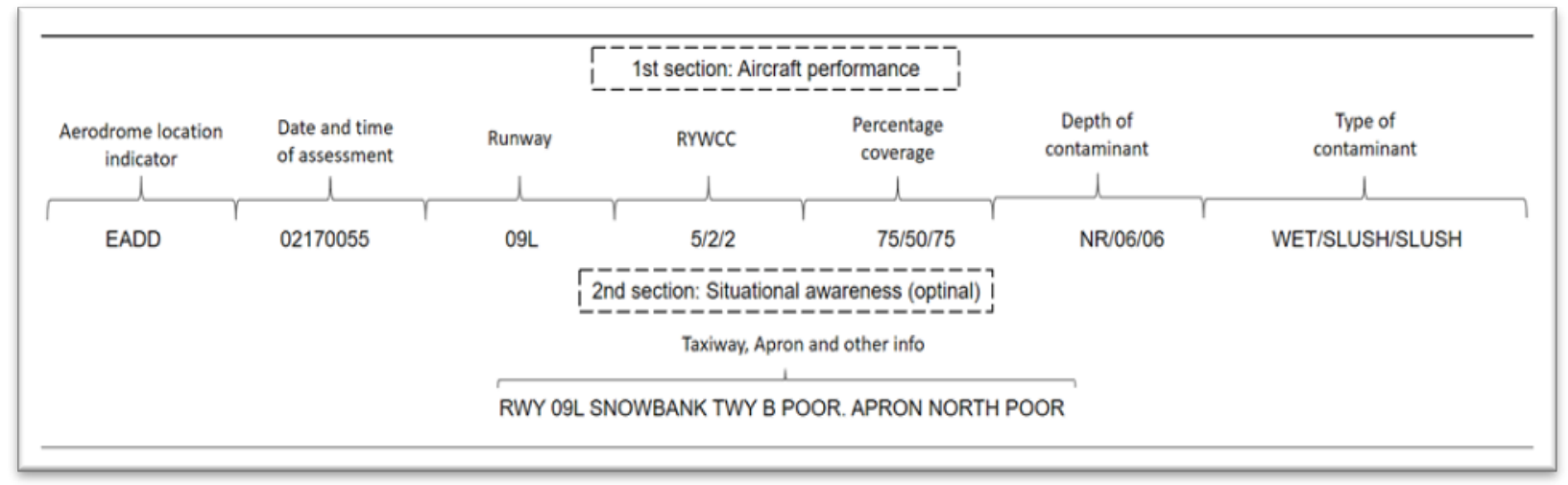

Figure 5: An Example of RCR1

RCR process shall be initiated whenever a significant change in runway surface conditions occurs. A change in the runway surface condition is considered significant whenever there is any change in the RWYCC, contaminant type and depth, reportable contaminant coverage/percentage, and any other information such as a pilot report of runway braking action (ICAO, 2020c). Reporting of the

1 "NR" is used when there is no reporting on the surface or if the contamination on the surface is less than $10 \%$. 
runway surface condition should continue to reflect significant changes until the runway is no longer contaminated.

\section{SNOWTAM}

SNOWTAM is a special series NOTAM given in a standard format providing a surface condition report notifying the presence or cessation of hazardous conditions due to snow, ice, slush, frost, standing water or water associated with snow, slush, ice or frost on the movement area (ICAO, 2018b:1-8).

SNOWTAM reflects RCR including information as shown in Table 3. A new SNOWTAM is related to the latest RCR for active runways at the airport and is issued every time a new RCR is received (ICAO, 2020d).

Table 3: An Example of SNOWTAM

\begin{tabular}{|c|c|}
\hline SNOWTAM & $\begin{array}{l}\text { Explanation } \\
\text { Abbreviations }\end{array}$ \\
\hline GG EADBZTZX & Orgin of SNOWTAM \\
\hline 111045 EADDYNYX & date/time of SNOWTAM \\
\hline SWEA0124 & $\begin{array}{lr}S W= & \text { SNOWTAM } \\
E A=\text { Region } & \text { and } \\
\text { SNOWTAM serial number }\end{array}$ \\
\hline EADD 011110352 & $\begin{array}{l}\text { Aerodrome location } \\
\text { indicator and date/time of }\end{array}$ \\
\hline $\begin{array}{l}\text { (SNOWTAM } 0124 \\
\text { EADD } \\
01111035 \quad 09 \mathrm{R} \quad 5 / 5 / 5 \\
\text { NR/NR/NR NR/NR/ } \\
\text { NR FROST/FROST/ } \\
\text { FROST) }\end{array}$ & observation \\
\hline
\end{tabular}

SNOWTAM numbered 124 published at

1045 UTC on the 11th of the month contains the runway status report of the observation at 10:35

UTC on the 11th day of the 1st month at EADD airport.

When a new SNOWTAM is issued for an airport, the previous SNOWTAM (if any) will automatically cancel and replace the old one. If a SNOWTAM is not been issued within 8 hours from the previous SNOWTAM time, the old SNOWTAM terminates automatically by the system and is considered normal for airport operations. If the phenomenon disappears within 8 hours, SNOWTAM must be canceled (ICAO,2020c).

\section{GRF Stakeholders and Information Flow}

GRF includes all stakeholders involved in the process of collecting data, converting data into structured operational information, and communicating structured information to endusers for assessment and reporting of runway surface conditiox|ns (ICAO, 2019b). Airport operators, air navigation service providers (ANSPs) and aircraft operators are the main stakeholder organizations in the GRF process. The flow of information between these stakeholders is shown in Figure 6.

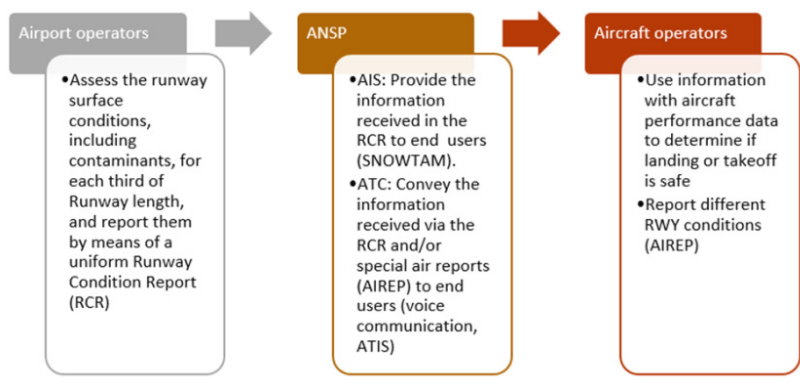

Figure 6: The Flow Chart of GRF

\section{DISCUSSION}

Throughout the history of civil aviation, there have been many accidents during take-off and landing phases of aircraft. Most accidents occurred as a result of runway excursions during take-off or landing. Runway excursions depend on many relevant factors, including wind, runway surface conditions, required landing or takeoff distance, the presence of obstacles, runway distance available, presence and dimensions of runway protection areas (Valdés et al., 2011). However, among these factors, runway surface conditions adversely affect braking performance and directional control of aircraft, caused serious risks in terms of flight safety.

Developed by ICAO to ensure that runway surface conditions are matched with aircraft performance data, GRF does not require any changes or 
updates to aircraft and ATM systems. Similarly, there is no infrastructure requirement at airports. There are some requirements and measures to be taken at the operational level with GRF. In order to determine deviations and deficiencies occurring at the regional or national level in GRF, audits should be carried out by all organizations, especially by ICAO, and the process should be followed closely. The points to be considered in this context are as follows;

a. RCR must be submitted to include all information for the assessment of relevant runway conditions for aircraft performance assessment.

b. Airport personnel must have sufficient knowledge and skills to assess runway surface conditions and determine an accurate RWYCC.

c. Air traffic management personnel in process of transferring information and flight crews assessing information should have the necessary training.

d. A full coordination process should be carried out with relevant stakeholders.

The most important component of GRF is RCR. Global implementation of RCR including comprehensive standardized information of runway surface conditions' effects on aircraft landing and take-off performance, offers significant benefits in the development of the aviation industry. These are listed below;

a. It provides standardization by creating a more understandable and acceptable report by avoiding the application of different methods at a global level.

b. It creates a common language among all stakeholders in the report generation, publishing and assessment process.

c. It allows the flight crew to compare performance information provided by aircraft manufacturers with runway surface conditions, and ensures an exact determination of take-off and landing performance.

d. It improves runway safety by a better understanding of runway surface conditions in all climatic conditions.

e. It increases the vision of runway efficiency and related operations at the airport by keeping uncertainties to a minimum, especially in bad weather conditions.

f. It reduces environmental impacts with optimum aircraft performance and flight times.

Another important tool in the implementation of the GRF is RCAM. RCAM has 7 braking action levels defined by RWYCCs numbered from 0 to 6 . In the assessment process, the range from 1 to 5 is focused, because these values correspond to the most frequently reported conditions globally. RWYCC 6 means a dry runway with worse conditions canceled by previous reports. On the other side, RWYCC 0 refers to very slippery runway surface conditions posing a serious risk to flight safety. In such conditions, the runway must be closed to operations and situations minimizing braking performance on the runway surface must be mitigated. For this reason, the runway should be constantly monitored. The frequency of monitoring the runway varies according to prevailing weather conditions. In this process, deterioration occurs over time due to factors such as the rate of use on the runway surfaces and exposure to different weather conditions should also be taken into account. GRF enables continuous monitoring of runways and keeps them in a condition not causing very slippery under the rain.

Visual observation is the main tool for recording information to ensure standard reporting by continuously monitoring the GRF runway surfaces. No equipment for runway friction is used with GRF. The use of friction-measuring devices available in many airports to determine runway surface conditions is made according to criteria determined or accepted by states (ICAO, 2018a). However, friction measuring equipment values are no longer used to determine and report surface conditions because joint industry and multi-national government tests have not established a reliable correlation between runway 
friction values and relationship to aircraft braking performance (Federal Aviation Administration (FAA), 2019). The use of numbers generated by these devices was operationally stopped by ICAO in 2014 with changes in SNOWTAM format. ICAO does not consider any specific equipment required to produce suitable RCRs under the GRF. Observations depend on the experience and skill of the staff. The more precise the information available in the GRF, the higher increase in flexibility, efficiency and safety can be expected in adverse weather conditions changing rapidly. The quality of information can be increased by qualitative and quantitative extensions of observation and calculation methods. In a study to support decision-making in optimizing the number of runway observations, runway maintenance and removal of contaminants from the surface, different methods were investigated for advanced automated vehicles for continuous assessment of runway surface condition. It was concluded that the study contributed to improving the flight safety of automated surveillance vehicles (Vorobyeva et al., 2020). Automatic observation tools located in and around the runway surface benefit from more frequent observations and the prevention of human errors. Supporting GRF with automatic observation tools as well as human observations can be an important element in overcoming human-induced difficulties and increasing confidence in the system.

GRF consists of three stages standardizing based on safety as shown in Figure 7. In the first phase, it provides monitoring, assessment and reporting related to operational procedures and performance at a global scale. In the second phase, it contributes to the increase of situational awareness and decision-making process with the distribution of information including standard reports over ATC, ATIS and SNOWTAM. In the third phase, it enables performance-related reports to be compared with aircraft performance. Among these three phases, there is continuous communication for monitoring and evaluating runway surface conditions. However, GRF has brought some difficulties to overcome. Decision- making for the varying conditions existing along the runway, the length of the ATIS broadcast at aerodromes with more than one runway, and the training of the relevant personnel stand out among these challenges. In addition, the fact that the GRF is put forward by ICAO as a requirement only airports open to international traffic, and the application at other airports is left to the choice of states is likely to cause inquiries about the new method purposing to standardize at the global level for flight safety.

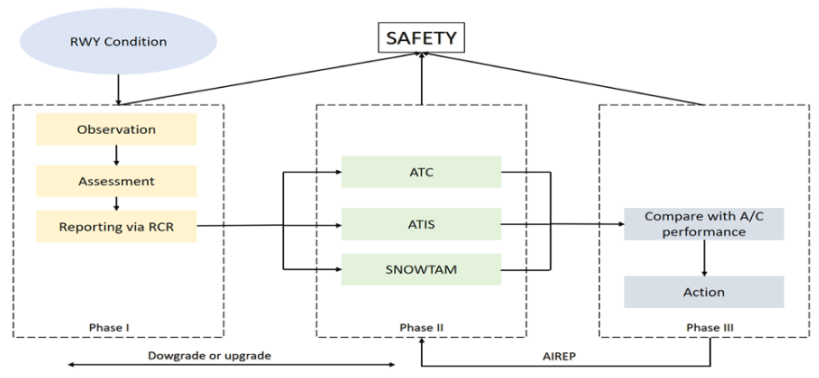

Figure 7. The Phases of GRF

\section{CONCLUSION}

The Chicago Convention, signed on December 7 , 1944 , is a milestone for civil aviation and formed the basis for the global level procedures to support the safe and orderly development of aviation by ICAO. On this basis, studies are carried out in all areas to reduce the risks endangering flight safety and to make them manageable. One of these studies is related to runway excursion accidents due to runway surface conditions causing serious fatal accidents. As a result of long-term studies, ICAO develops a new method known as GRF at the global level to be used in the assessment and reporting of runway surface conditions to reduce the risks associated with runway excursion. GRF method considered one of the most important milestones in the history of civil aviation aims to provide a solution to a long-standing unresolved problem of comparing aircraft performance with runway condition information more objectively.

GRF applies not only to winter conditions but also to wet runways in all seasonal conditions. This method is simply understood and applied globally. GRF is an important tool reducing the 
risk of runway excursion and increasing the safety of runway operations. In addition, standard runway surface reporting based on aircraft performance allows operations to continue and determination of landing and take-off distances at the optimum level.

Matching the standard reports obtained through observations with the performance data provided by aircraft manufacturers is a structural advantage of the GRF method. In the GRF method, the basic element in observations is people. To make these observations more frequently, sensors embedded in the runway or offer mobile use are in the development process. While these efforts are encouraged by ICAO, for now, there is no standard equipment or tools for measuring and reporting runway surface conditions.
GRF addresses all risks related to runway safety with the findings obtained as a result of investigating accidents and serious incidents caused by runway surface conditions. The aviation industry needs to rebuild trust in people by trying to make all risks controllable to overcome the crisis it faces, such as epidemics. In this context, ensuring the safety of aircraft operations is to be one of the most important elements of the aviation industry. GRF putting forward to reduce the risks associated with runway excursion as a result of a long-term study contributes to increasing people's confidence in aviation.

It is assessed that the data to be obtained from the application of GRF will be beneficial in the process of mitigating the risks arising from runway surface conditions in aviation accidents and making them manageable.

\section{REFERENCES}

1. Boeing (2021), Statistical Summary of Commercial Jet Airplane Accidents, Page.15 https:// www.boeing.com/resources/boeingdotcom/company/about_bca/pdf/statsum.pdf Date of Access: 01.04.2021

2. CAP 153 G-ALZU AS 57 (2021). https://assets.publishing.service.gov.uk/ media/5422f1ebed915d137100039d/CAP_153_G-ALZU_6_Feb_1958_Elizabethan_ Munich_1959_1st_German_Acc_Report.pdf Date of Access: 12 April 2021

3. EUROCONTROLL (2021). The Global Action Plan for the Prevention of Runway Excursions (GAPPRE) https://www.eurocontrol.int/sites/default/files/2021-01/global-action-plan-for-theprevention-of-runway-excursions-report.pdf Date of Access: 15.04.2021

4. European Union Aviation Safety Agency (EASA) (2020). Annual Safety Review https://www. easa.europa.eu/document-library/general-publications/annual-safety-review-2020 Date of Access: 20.04.2021

5. European Union Aviation Safety Agency (EASA) (2021a). The runway excursion challenge https:/www.easa.europa.eu/community/topics/runway-excursions Date of Access: 20 April 2021

6. European Union Aviation Safety Agency (EASA) (2021b). GRF webinar 10 March $2021 \mathrm{https}: / /$ www.easa.europa.eu/newsroom-and-events/events/implementation-workshop-global-reportingformat-runway-surface Date of Access: 20 April 2021

7. Federal Aviation Administration (FAA) (2019). Safety Alert for Operators 19001 (SAFO) https:/www.faa.gov/other_visit/aviation_industry/airline_operators/airline_safety/safo/all_safos/ media/2019/SAFO19001.pdf Date of Access: 20 April 2021

8. International Civil Aviation Organization (ICAO) (2016). Adoption of Amendment 13 to Annex 14, Vol I. State Letter AN 4/1.2.26-16/19 dated 5 April 2016

9. International Civil Aviation Organization (ICAO) (2018a). Annex 14 Aerodromes Volume I Aerodrome Design and Operations 8th edition July 2018 Amend.15

10. International Civil Aviation Organization (ICAO) (2018b). Doc 10066 Procedures For Air Navigation Services (PANS) Aeronautical Information Management 1st Edition

11. International Civil Aviation Organization (ICAO) (2019a). State of Global Aviation Safety. https:// www.icao.int/safety/Documents/ICAO_SR_2019_29082019.pdf

12. International Civil Aviation Organization (ICAO) (2019b). Circular 355 Assessment, Measurement 
and Reporting of Runway Surface Conditions

13. International Civil Aviation Organization (ICAO) (2020a). Changes to applicability dates of SARPs and PANS related to the enhanced global reporting format for assessing and reporting runway surface conditions (GRF) due to the COVID-19 pandemic. Adoption of Amendments: 80 to Annex 3; 45 to Annex 6, Part I; 38 to Annex 6, Part II; 107 to Annex 8; 16 to Annex 14, Volume I; and 42 to Annex 15, and approval of Amendments: 10 to PANS-ATM; 4 to PANS-Aerodromes; and 2 to PANS-AIM: State Letter AN 10/1.1, AN 11/1.3.33, AN 11/6.3.32, AN 3/5.13, AN 4/1.2.29, AN 2/2.7, AN 13/2.1, AN 4/27 and AN 2/33-20/73 dated 30 July 2020

14. International Civil Aviation Organization (ICAO) (2020b). Doc 9981 Procedures For Air Navigation Services (PANS) Aerodromes 3rd Edition 2020 Amendment 3

15. International Civil Aviation Organization (ICAO) (2020c). Webinar- SNOWTAM 2020 Introduction of the ICAO EUR/NAT Guidance on the Issuance of SNOWTAM 20 May 2020

16. International Civil Aviation Organization (ICAO) (2020d). European and North Atlantic Office EUR Doc 041 Guidance on the Issuance of SNOWTAM

17. International Civil Aviation Organization (ICAO) (2021a). https://unitingaviation.com/news/ safety/runway-surface-conditions-the-global-reporting-format Date of Access: 20 April 2021

18. International Civil Aviation Organization (ICAO) (2021b). https://www.icao.int/safety/Pages/ GRF.aspx Date of Access: 20 April 2021

19. Okafor, E. G., Jemitola, P. O., \& Soladoye, M. A. (2018). Assessment of runway excursion causal factors and mitigation strategies. Nigerian Journal of Technology, 37(3), 619-625.

20. Piyush, G., Hemantkumar, G. S. (2014) "Runway Excursion: A Problem" IOSR Journal of Mechanical and Civil Engineering Vol. 11 Issue 3, 2014, pp. 75-78

21. Valdés, R. M. A., Comendador, F. G., Gordún, L. M., \& Nieto, F. J. S. (2011). The development of probabilistic models to estimate accident risk (due to runway overrun and landing undershoot) applicable to the design and construction of runway safety areas. Safety science, 49(5), 633-650.

22. Vorobyeva, O., Bartok, J., Šišan, P., Nechaj, P., Gera, M., Kelemen, M., ... \& Gaál, L. (2020). Assessing the Contribution of Data Mining Methods to Avoid Aircraft Run-Off from the Runway to Increase the Safety and Reduce the Negative Environmental Impacts. International journal of environmental research and public health, 17(3), 796 